\section{Review}

Dr. Md. Shahed Rafi Pavel

BDS, MPH

Asst. Professor

Dept. of Dental Public Health

City Dental College, Dhaka

Prof. Dr. Md. Anower Hussain Mian

BDS, DDS, PhD (Japan)

Post doc. fellow (USA)

Prof. (cc) \& Head Dept. of General

\& Dental Pharmacology

City Dental College \& Hospital, Dhaka

Dr. AKM Habibullah

BDS

Lecturer

Dept. of Oral Anatomy and Physiology

City Dental College, Dhaka

Prof. Dr. Md. Zahid Hossain

BDS, PGD, PhD

Professor

Dept. of Periodontology,

Oral Pathology \& Oral Medicine

City Dental College, Dhaka

Correspondence to:

Dr. Md. Shahed Rafi Pavel

BDS, MPH

Asst. Professor

Dept. of Dental Public Health

City Dental College, Dhaka

e-mail:msrpavel@gmail.com

\title{
Periodontitis and Cardiovasculardisease: Association and Risk
}

\begin{abstract}
:
Periodontitis has been associated with an increased risk of cardiovascular events. Two internet databases were selected in search of appropriate papers for the study purpose: i)the National Library of Medicine,Washington DC,USA (MEDLINE-PubMed) and ii) HINARI Access to Research in Health Program,World Health Organization, Geneva,Switzerland.Both databases were searched from 1985 to 2009.In the past decades, there has been renewed interest in the old hypothesis that infections increase the risk of developing cardiovascular disease.Atherosclerosis has a major inflammatory component and the main underlying pathological pathway for cardiovascular disease (CVD). Periodontal pathogens may be involved in the initiation and progression of atherosclerosis and subsequent coronary heart disease.Periodontal pathogenPorphyromonasgingivalis caused atherosclerosis in experimental animals and have been found in human atherosclerotic lesions. The nature of association is unclear because both periodontitis and CVD share a host of risk factors.Epidemiological studies, mainly observational studies (case-control,cross-sectional and prospective cohort studies) are usually the first to generate association data between exposure and adverse health outcomes. Clinical trials with statistically significant positive outcomes are easy to interpret and indicate that the tested intervention is effective in favorably altering the adverse health outcomes.Available evidences suggest that having periodontitis contributes to the total infection and inflammation burden and may contribute to cardiovascular events in susceptible subjects. The impact of periodontal therapy must be further investigated.
\end{abstract}

Keywords: Periodontitis,associations, cardiovascular disease (CVD).

\section{Introduction:}

Periodontitis is a progressive inflammation, leading to the distraction of the tooth supporting tissue and alveolar bone caused by a chronic, mixed infection. The infectious etiology of periodontitis is well established. ${ }^{1}$ Cardiovascular diseases comprises a variety of heart and vascular conditions including ischemia, atherosclerosis, peripheral artery disease, infective endocarditis and acute myocardial infraction. ${ }^{2}$ Coronary heart disease (CHD) refers to the failure of coronary circulation to supply adequate circulation to cardiac muscle. Atherosclerosis is the main underlying pathological pathway for CHD. Periodontal pathogens may be involved in the initiation and progression of atherosclerosis and subsequent coronary heart disease. This was supported by epidemiological case-control studies but also by animal experiments using Apo lipoprotein E-deficient mice. ${ }^{3}$ Periodontal pathogens Porphyromonasgingivalis $(P$. gingivalis) cause atherosclerosis in experimental animals and have been found in human atherosclerotic lesions. ${ }^{4} P$. gingivalis has also been recorded to give rise to inflammatory changes with high affinity to the inner lining of blood vessels. ${ }^{5}$ 
${ }^{5}$ Cross-sectional and longitudinal epidemiological studies have shown that cases with periodontitis were at a significantly increased risk of developing $\mathrm{CHD} .{ }^{6}$ Recent systematic reviews and meta-analysis have identified that elevated antibody titers to bacteria associated with periodontitis can be linked to $\mathrm{CHD}$ risk. ${ }^{7}$ Many epidemiological studies have identified statistically significant associations provided high odds ratio (OD)s between Periodontitis and CHD. ${ }^{8}$ Periodontitis is a chronic inflammatory disease, that can result in increased levels of certain serological riskmarkers for atherosclerosis as for example C-reactive protein (CRP), leukocytes, certain cytokines, the lipid profile and fibrinogen. This increases the risk of thrombocytes to coagulate and create atheromatous plaque. A recent systematic review concluded that there was strong evidence from cross-sectional studies that plasma CRP was elevated in periodontitis affected subjects compared with controls. ${ }^{9}$

\section{Periodontitis-CVD Association Studies}

The relationship between periodontitis and CVD has been summarized in two recent publications based on the principles of meta-analysis. The analysis by Behekar et al. including five prospective cohort studies $(86,092$ patients) indicated that individuals with periodontitis had a 1.14 times higher risk of developing coronary heart disease than subjects without periodontitis [relative risk $1.14,95 \%$ confidence interval (CI) 1.01-1.2,p<0.001].The case-control studies (1423 patients) showed greater odds of an association between periodontitis and coronary heart disease [odds ratio $(\mathrm{OR}) 2.2,95 \% \mathrm{Cl} 1.6-3.1, \mathrm{p}<0.001$ ]. The prevalence of coronary heart disease in the crosssectional studies reviewed $(17,724$ patients) was greater among individuals with periodontitis than in subjects without periodontitis. ${ }^{10}$

Table-1 provides a summary based on studies on the association and risks between periodontitis and cardiovascular diseases.Meta-analysis of prospective and retrospective follow-up studies have shown that periodontal disease may only slightly increase the risk of cardiovascular disease. ${ }^{10}$ Furthermore,when adjusting for demographic factors, studies have shown that the association between periodontitis based on clinical attachment level measurements in relation to coronary artery calcification (Agatasonscoreat http://circ.ahajournals.org/content/108/8/e50) does not demonstrate a significant association between the two conditions. ${ }^{11}$ In contrast, others have found a significant relationship between periodontal status based on clinical measures of probing pocket depth/clinical attachment loss and acute myocardial infraction. ${ }^{12}$ Most studies provide odds ratios of periodontitis (defined by clinical measures of probing pocket depth and clinical attachment levels) as a risk for cardiovascular disease at levels less than a ratio $3: 1.13$ Studies resulting in higher ORs have commonly used alveolar bone loss as the definition of periodontitis rather than measures of probing pocket depth and clinical attachment level. ${ }^{14}$ The study by Beck et al. confirmed that clinical signs(bleeding on probing, probing pocket depth, clinical attachment levels) are not representative for impact of cumulative effects of periodontitis on systemic health. Disparity in prevalence rates of periodontitis in study populations with different age groups,ethnicity, and geographic location makes it difficult to assess the likelihood of an association between periodontitis and cardiovascular diseases. ${ }^{15}$

Table-1: Studies assessing association between cardiovascular disease and periodontitis.

\begin{tabular}{|c|c|c|c|c|}
\hline $\begin{array}{l}\text { Briggs et al. } \\
(2006)\end{array}$ & Case-control study & $\begin{array}{l}92 \text { periodontitis } \\
\text { cases and } 79 \text { healthy controls }\end{array}$ & $\begin{array}{l}\text { Median CRP in periodontitis } \\
\text { subjects } \\
2.1 \text { and } 1.4 \mathrm{mg} / \mathrm{l} \text { in controls. } \\
\text { Mean age } \\
\text { was } 58 \text { years }\end{array}$ & $\begin{array}{l}\text { Periodontitis and risk for coronary } \\
\text { heart disease } \\
\text { OR=3 1,95\% Cl: } 1.0-9.2(p<0.05) \\
\text { CRP (high/low): Periodontitis OR } \\
0.1,95 \% \mathrm{Cl}: 0.5-2.5 \mathrm{NS}\end{array}$ \\
\hline $\begin{array}{l}\text { Zaremba et } \\
\text { al.(2007) }\end{array}$ & Bacteria & $\begin{array}{l}\text { A. actinomycetemcomitans } \\
\text { C. rectus, F. nucleatum } \\
P \text {. gingivalis, } P \text {. intermedia } \\
T \text {. forsythia, } T \text {. denticola }\end{array}$ & $\begin{array}{l}\text { The incidence of periodontal } \\
\text { bacteria in } \\
\text { atherosclerotic plaque by DNA } \\
\text { analysis from } \\
20 \text { subjects was studied }\end{array}$ & $\begin{array}{l}\text { A. actinomycetemcomitans in } 1 / 20 \\
\text { C. rectus in } 4 / 20 \\
\text { F. nucleatum } 5 / 20 \\
\text { P. intermedia in } 33 \% \\
\text { P. gingivalis in } 10 / 20 \\
\text { T. Denticola in } 6 / 20 \\
\text { T. forsvthia in } 5 / 20\end{array}$ \\
\hline
\end{tabular}




\begin{tabular}{|c|c|c|c|c|}
\hline $\begin{array}{l}\text { Lessem et al. } \\
(2002)\end{array}$ & $\begin{array}{l}\text { Retrospective case } \\
\text { series }\end{array}$ & $\begin{array}{l}\text { Radiographic evidence of } \\
\text { alveolar bone loss }\end{array}$ & $\begin{array}{l}\text { Heart transplant cases were } \\
\text { searched through medical } \\
\text { records }\end{array}$ & $\begin{array}{l}76 \% \text { of cases had periodontitis } \\
\text { before heart transplantation. }\end{array}$ \\
\hline $\begin{array}{l}\text { Meurman et al. } \\
(2003)\end{array}$ & $\begin{array}{l}\text { Case-control study of } 256 \\
\text { subjects with } \\
\text { heart disease and } 250 \\
\text { controls }\end{array}$ & $\begin{array}{l}\text { Revised version of the dental } \\
\text { index as described by Mattila et } \\
\text { al., } 1989 \text { and based on clinical } \\
\text { and radiological dental } \\
\text { examinations (MDI index) }\end{array}$ & $\begin{array}{l}\text { Serum samples of } 256 \\
\text { patients with New York } \\
\text { Heart Association class II- IV } \\
\text { heart disease }\end{array}$ & $\begin{array}{l}\text { High MDI/heart disease } \\
\text { OR=1.3 95\% Cl: } 1.2-1.5 \\
\text { Gingivitis/heart disease } \\
\text { OR=3.4, 95\% Cl: } 1.7-6.9\end{array}$ \\
\hline $\begin{array}{l}\text { Persson et al. } \\
(2003 c)\end{array}$ & $\begin{array}{l}\text { Matched case- } \\
\text { control study based on } \\
\text { consecutive cases of acute } \\
\text { coronary syndrome }\end{array}$ & $\begin{array}{l}\text { Alveolar bone loss } \mathrm{X} 4 \mathrm{~mm} \text { at } \\
\text { approximal sites } \\
\text { Different proportional rates } \\
\text { from } 010 \% \text { to } 450 \% \text { of sites } \\
\text { with alveolar bone loss }\end{array}$ & $\begin{array}{l}\text { Acute coronary syndrome } \\
\text { consecutive cases with } \\
\text { hospital diagnosis. Age, } \\
\text { gender, smoking status, } \\
\text { socio-economic matched } \\
\text { controls through medical } \\
\text { examination }\end{array}$ & $\begin{array}{l}\text { All subjects: } \\
\text { Bone loss }>50 \% \\
\text { OR=14.1 } 95 \% \mathrm{Cl}: 5.5-28.2 \\
\text { Bone loss }>30 \% \text { of sites } \\
\text { OR }=12.95 \% \mathrm{Cl}: 4.7-35.3 \\
\text { in non-smokers: } \\
\text { OR }=5.995 \% \mathrm{Cl}: 1.4-24.4\end{array}$ \\
\hline $\begin{array}{l}\text { Ravon et al. } \\
(2003)\end{array}$ & Case-control study & $\begin{array}{l}\text { Bone loss } X 4 \mathrm{~mm} \text { at approximal } \\
\text { sites at } 430 \% \text { of sites }\end{array}$ & $\begin{array}{l}\text { Positive or negative duplex } \\
\text { ultrasonography }\end{array}$ & OR: $38.4,95 \%$ Cl: $10.6-138.7$ \\
\hline $\begin{array}{l}\text { Geerts et al. } \\
(2004)\end{array}$ & $\begin{array}{l}\text { Case-control study } 108 \\
\text { coronary heart } \\
\text { disease cases and } 62 \\
\text { healthy control subjects }\end{array}$ & $\begin{array}{l}\text { Periodontitis defined by probing } \\
\text { pocket depth. One site or more } \\
\text { X5mm New index for periodontal } \\
\text { infection risk index (PIRI) }\end{array}$ & $\begin{array}{l}\text { Hospital confirmed cases } \\
\text { with coronary heart disease in } \\
\text { treatment }\end{array}$ & $\begin{array}{l}\text { OR: } 6.5,95 \% \mathrm{Cl} 1.8-23.0) \\
\text { A dose response curve for the PIRI } \\
\text { index and coronary heart disease }\end{array}$ \\
\hline $\begin{array}{l}\text { Nakib et al. } \\
\text { (2004) }\end{array}$ & $\begin{array}{l}\text { Epidemiological } \\
\text { study of } 6931 \\
\text { subjects (1996-2000) }\end{array}$ & $\begin{array}{l}\text { Clinical attachment level } \\
\text { X3mm was used to define } \\
\text { periodontitis }\end{array}$ & $\begin{array}{l}\text { Coronary artery calcification } \\
\text { (Agatston score) }\end{array}$ & $\begin{array}{l}\text { OR: } 1.5,95 \% \text { Cl: } 0.5-4.2 \\
\text { Not statistically significant } \\
\text { Adjusted for demographic factors }\end{array}$ \\
\hline $\begin{array}{l}\text { Shimazaki et al. } \\
(2004)\end{array}$ & $\begin{array}{l}\text { Case-control study of } 957 \\
\text { subjects }\end{array}$ & $\begin{array}{l}\text { Periodontal status of } 1,111374 \\
\text { males and } 583 \text { female Japanese } \\
\text { with X10 teeth was studied. }\end{array}$ & $\begin{array}{l}\text { Subjects without heart } \\
\text { disease as defined by ECG } \\
\text { analysis were studied }\end{array}$ & $\begin{array}{l}\text { PPD definition: } \\
\text { OR:1.7 95\% Cl: } 1.01-2.0 \\
\text { CAL definition } \\
\text { OR: } 1.7,95 \% \mathrm{Cl}: 1.1-2.7)\end{array}$ \\
\hline $\begin{array}{l}\text { Engebretson et } \\
\text { al. (2005) }\end{array}$ & Case-control study & $\begin{array}{l}\text { Radiographic assessment of } \\
\text { carotid calcification and alveolar } \\
\text { bone loss }\end{array}$ & Ultrasound & $\begin{array}{l}\text { OR: } 3.6,95 \% \text { Cl: } 1.4-9.7 \\
\text { Association between bone loss and } \\
\text { carotid artery plaque }\end{array}$ \\
\hline $\begin{array}{l}\text { Buhlin et al. } \\
(2005)\end{array}$ & $\begin{array}{l}\text { Case-control study } \\
\text { Women only }\end{array}$ & $\begin{array}{l}\text { Assessments were performed } \\
\text { for: Number of remaining teeth and } \\
\text { pathological periodontal pockets (X4mm), } \\
\text { Denture/no dentures Vertical bone loss }\end{array}$ & $\begin{array}{l}\text { Subjects treated for coronary } \\
\text { heart disease (angioplasty, by- } \\
\text { pass grafting }\end{array}$ & $\begin{array}{l}\text { Periodontal pockets and } \\
\text { coronary heart disease } \\
\text { OR: } 3.8,95 \% \mathrm{Cl}: 1.68-8.74), \\
\text { Dentures and coronary heart } \\
\text { disease: OR of } 4.6(0.99-21.28) \text {. } \\
\text { No relationship to vertical bone loss }\end{array}$ \\
\hline $\begin{array}{l}\text { Cueto et al. } \\
(2005)\end{array}$ & Case-control study & $\begin{array}{l}\text { Percentage of sites with clinical } \\
\text { attachment loss and probing } \\
\text { pocket depth were dichotomized }\end{array}$ & $\begin{array}{l}\text { Medically confirmed acute } \\
\text { coronary syndrome }\end{array}$ & Adjusted OR: 3.1 \\
\hline $\begin{array}{l}\text { Holmlund et al. } \\
(2006)\end{array}$ & $\begin{array}{l}\text { Case-control study, } \\
\text { referred dental } \\
\text { patients for } \\
\text { periodontal care }\end{array}$ & $\begin{array}{l}\text { Periodontal index scale } 0-4 \\
\text { dependent on extent of bone loss } \\
\text { (defined as } 41 / 3 \text { root length, } \\
\text { bleeding on probing and teeth } \\
\text { with furcation }\end{array}$ & $\begin{array}{l}\text { Subject self-report of a } \\
\text { history of myocardial } \\
\text { infarction or high blood } \\
\text { pressure (not defined) }\end{array}$ & $\begin{array}{l}\text { Periodontitis and myocardial } \\
\text { infarction } \\
\text { OR: } 2.7,95 \% \mathrm{Cl}: 1.1-6.5\end{array}$ \\
\hline $\begin{array}{l}\text { Spahr et al. } \\
\text { (2006) }\end{array}$ & Case-control study & CPITN index & $\begin{array}{l}\text { Angiography confirmed } \\
\text { coronary heart disease and } \\
\text { controls with no medical history }\end{array}$ & OR, $1.6795 \% \mathrm{Cl}, 1.08-2.58$ \\
\hline $\begin{array}{l}\text { Geismar et } \\
\text { al.(2006) }\end{array}$ & Case-control study & $\begin{array}{l}\text { Full mouth periodontal exam. } \\
\text { Radiographic assessments }\end{array}$ & $\begin{array}{l}\text { Routine serum assay. Confirmed } \\
\text { medical conditions coronary } \\
\text { disease }(0110) \text { or health } \\
(n 5140)\end{array}$ & $\begin{array}{l}\mathrm{OR}=6.6 \text { (95\% Cl: } 1.9 \text { to } 25.6 \text { Bone } \\
\text { Loss }\end{array}$ \\
\hline $\begin{array}{l}\text { Rech et al. } \\
(2007)\end{array}$ & Case-control study & $\begin{array}{l}\text { Probing pocket depth } 43 \mathrm{~mm} \text {, } \\
\text { and/or bleeding on probing, and/ or loss of } \\
\text { clinical attachment, and /or bone loss. } \\
\text { Diagnosis defined by clinicians unaware of } \\
\text { medical status }\end{array}$ & $\begin{array}{l}\text { ACS consecutive cases with } \\
\text { hospital diagnosis }\end{array}$ & OR54.5 95\% Cl: 1.3-15.6 \\
\hline $\begin{array}{l}\text { Seinost et al. } \\
(2005)\end{array}$ & Case-control study: & $\begin{array}{l}61 \text { subjects of } 3 \\
\text { months duration including debridement } \\
\text { and antibiotics in treatment group }\end{array}$ & $\begin{array}{l}\text { Change in serum CRP following } \\
\text { treatment }\end{array}$ & $\begin{array}{l}\text { Healthy subjects } 0.8 \mathrm{mg} / \mathrm{l}(\mathrm{SD} 0.8) . \\
\text { Periodontitis subjects before } \\
\text { treatment } \\
1.7 \mathrm{mg} / \mathrm{l}(\mathrm{SD} 1.6) \\
\text { Periodontitis subjects after } \\
\text { treatment } 1.1 \text { (SD10.9) }\end{array}$ \\
\hline $\begin{array}{l}\text { Best et al. } \\
\text { (2005) }\end{array}$ & Case-control study: & $\begin{array}{l}1131 \text { older subjects with or without } \\
\text { periodontitis/positive } \\
\text { bacterial enzyme test (BANA test) and } \\
\text { serum markers of inflammation: CRP, II-6, } \\
\text { TNF-a }\end{array}$ & $\begin{array}{l}\text { Periodontal disease and infection } \\
\text { may be modifiable risk indicators } \\
\text { to elevated levels of CRP in older } \\
\text { people }\end{array}$ & $\begin{array}{l}\text { Periodontitis in the presence of } \\
\text { periodontitis (BANA test) is linked to } \\
\text { elevated TNF-a, and IL-6 levels in } \\
\text { older subjects. This may specifically } \\
\text { suggest the link between } \\
\text { periodontitis and } \\
\text { cardiovascular diseased susceptible } \\
\text { subiects }\end{array}$ \\
\hline
\end{tabular}




\begin{tabular}{|c|c|c|c|c|}
\hline Authors & Study design & Periodontal diagnosis & Medical diagnosis & Association \\
\hline $\begin{array}{l}\text { Mattila et al. } \\
\text { (1989) }\end{array}$ & Case-control study & $\begin{array}{l}\text { Total dental index:caries, periodontitis, } \\
\text { peri-apical lesions, abscess ( } 14 \text { criteria). } \\
\text { Subjects were assigned a score from } 0 \text { to } \\
10\end{array}$ & $\begin{array}{l}\text { ACS consecutive cases, hospital } \\
\text { confirmed cases }\end{array}$ & $\begin{array}{l}\text { ACS-cholesterol }(p<0.001) \text { ACS- } \\
\text { dental index }(p<0.01) \\
\text { ACS-smoking }(p<0.01) \\
\text { Odds ratio was not calculated }\end{array}$ \\
\hline $\begin{array}{l}\text { DeStefano } \\
\text { et al. (1993) }\end{array}$ & $\begin{array}{l}\text { Epidemiological } \\
\text { study based on the } \\
\text { NHANES I and } \\
\text { the(NHEFS) data }\end{array}$ & $\begin{array}{l}\text { Russell index } \\
\text { Gingivitis } \\
\text { Periodontitis }\end{array}$ & $\begin{array}{l}\text { Incidence of coronary } \\
\text { heartdisease (CHD) 1974-1987 }\end{array}$ & $\begin{array}{l}\text { CHD-gingivitis: } \\
\text { OR = 0.95, 95\% Cl: } 0.5-1.8 \\
\text { CHD-periodontitis: } \\
\text { OR = } 1.5,95 \% \text { Cl: } 0.8-3.0 \\
\text { CHD = CHD-Russell index: } \\
\text { OR }=1.1,95 \% \text { Cl: } 0.9-1.3\end{array}$ \\
\hline $\begin{array}{l}\text { Beck et al. } \\
(1996)\end{array}$ & $\begin{array}{l}\text { A cohort study with } \\
\text { combined data from (1) the } \\
\text { Normative Aging Study, (2) } \\
\text { the Dental Longitudinal } \\
\text { Study (Veterans } \\
\text { Affair) }\end{array}$ & $\begin{array}{l}\text { Bone loss score based on } 5 \text { different } \\
\text { categories was } \\
\text { assessed. More than } 20 \% \text { sites } \\
\text { with bone loss=periodontitis }\end{array}$ & $\begin{array}{l}\text { Coronary heart disease } \\
\text { including non-fatal } \\
\text { infarction, angina pectoris, } \\
\text { and coronary heart disease } \\
\text { death }\end{array}$ & $\begin{array}{l}\text { OR=1.5 } \\
95 \% \text { Cl: } 1.01 \text { to } 2.1\end{array}$ \\
\hline $\begin{array}{l}\text { Morrison et al. } \\
\text { (1999) }\end{array}$ & $\begin{array}{l}\text { A retrospective study } \\
\text { 1972-1993, the Nutrition } \\
\text { Canadian Survey }\end{array}$ & Oral health /periodontitis & $\begin{array}{l}\text { Mortality experience in } \\
\text { coronary heart disease }\end{array}$ & $\begin{array}{l}\text { OR=2.2 } \\
95 \% \mathrm{Cl}: 1.3 \text { to } 3.7\end{array}$ \\
\hline $\begin{array}{l}\text { Persson et al. } \\
(2002)\end{array}$ & $\begin{array}{l}\text { Cross-sectional study of } \\
\text { older subjects } 651\end{array}$ & $\begin{array}{l}\text { Composite of radiographic } \\
\text { evidence and probing pocket } \\
\text { depth }\end{array}$ & $\begin{array}{l}\text { Self-reported history of } \\
\text { cardiovascular diseases } \\
\text { confirmed by medication } \\
\text { lists }\end{array}$ & OR=4.3 95\% Cl 2.4-7.9 \\
\hline
\end{tabular}

\section{Discussion:}

During the last two decades,there has been an increasing interest in the impact of oral health,specifically periodontitis, on cardiovascular disease.In one meta-analysis, the findings resulted in a conclusion that periodontitis and poor oral health overall indeed contribute to the pathogenesis of cardiovascular disease.16The meta-analysis by Baheker et al. has demonstrated that having periodontitis might enhance the risk for cardiovascular disease.Some studies have provided high ODs between periodontitis and cardiovascular diseases.Some people with periodontitis developed cardiovascular disease and many did not. Also, many people who do not have periodontitis develop cardiovascular disease, because there are several different causes. Individual clinicians are rarely in a position to confirm associations between exposure and disease though they may suspect them. For accurate information, they must turn to the medical literature, particularly to studies that are carefully constructer and involve a large number of patients. Thus the strength of an association between periodontitis and cardiovascular disease based on epidemiological, and cross sectional studies varies based on data from studies of different population and subjects.Available studies suggest that periodontitis prevalence in older subjects is high.17The aspect of aging as a factor in link between periodontitis and cardiovascular diseases; preventive care may, in fact,be the most important effort in reducing the risk for cardiovascular disease by maintaining healthy oral conditions.

\section{Conclusions:}

Available data suggest that periodontitis may have overall health consequences. The term "cardiovascular diseases" is a broad term and efforts are needed to specifically identify which cardiovascular diseases (i.e. stroke,acute coronary syndrome, and atherosclerosis) can be linked to periodontitis. It also raises a core question about the effect of periodontal treatment in reducing the risk of cardiovascular disease. It is likely that in future periodontal disease may be added to the list of factors, which are used to assess patients' risk profiles for cardiovascular disease should become a standard part of therapy for patients with above diseases. Finally, data suggesting an association between periodontal infections and cardiovascular diseases are strong enough to conclude that cardiologists and periodontists should vigorously pursue identification of the possible connections between these multifactorial diseases.

\section{References:}

1. Socransky SS,Haffajee AD.Periodontal microbial ecology.Periodontol 2000;38:35-87.

2. Karchmer AW. Infective endocarditis.A textbook of Cardiovasculer Medicine; 5th ed.:1077-99.

3. Lalla E,Lamster IB,Hofman MA, et al. Oral infection with a periodontal pathogen accelerates early atherosclerosis in apolipoprotein E-null mice. ArteriosclerThrombVascBiol 2003;23:1405-11.

4. Kozarov E,Sweier D,Shelburne. Detection of bacterial DNA in atheromatous plaques by quantitative PCR. Microbes \& Infection 2006;8:687-93.

5. Chiu B,Viira E,Evants RT, et al. Detection of an odontopathogen: Porphyromonasgingivalis in atherosclerotic plaques :an immunohistochemical and in situ hybridization study.AppllmmunohistochemMol Morph 2000 (In press).

6. Mattila KJ,Nieminen MS,Valtonen VV, et al. Association between dental health and acute myocardial infraction. $\mathrm{Br}$ Med J1989;298:779-81.

7. Mustapha IZ,Debrey S,Oladubu M, et al. Cardiovascular disease markers of systemic bacterial exposure in periodontal disease and risk:a systemic review and metaanalysis. J Periodontol2007;78:2289-2302. 
8. Geismer K,Stoltze K,Sigurd B, et al. Periodontal disease and coronary heart disease. Euro J Epidemiol2006;23:95103.

9. ParaskevasS, Huizinga JD, Loos BG. A systemic review and meta-analysis on $\mathrm{C}$-reactive protein in relation to periodontitis. J ClinPeriodontol2008;35:277-90.

10. Baheker AA,Singh S,Saha S, et al. The prevalence and incidence of coronary heart disease is significantly increased in periodontitis;a meta-analysis. American Heart J2007;154:830-37.

11.Nakib SA, Pankow JS, Beck JD, et al. Periodontitis and coronary artery calcification: the Atherosclerosis risk in community (ARIC) study. J Periodontol2004;75:505-10.

12. Cueto A, Mesa F, BravoM, et al. Periodontitis as risk factor for acute myocardial infraction. A case control study of Spanish adults. J Periodont Res2005;1:36-42.

13. Geismar K,Stoltze K,Sigurd B,et al. Periodontal disease and coronary heart disease. J Periodontol 2006;77:154754.

14. Rech RL, Nurkin N, da Cruz I, et al. Association between periodontal disease and acute coronary syndrome.ArquivosBrasileiror de Cardiologia 2007; 88:185-90.

15. BeckJD,Couper DJ, Falkner KL, et al. The periodontitis and vascular events(PAVE) pilot study: adverse events. J Periodontol2008;79:90-96.

16. Meurman JH, Sanz M, Janket SJ. Oral health, atherosclerosis, and cardiovascular disease.Crit Rev Oral Biol Med2004;15:403-13.

17.Krustrup U, Peterson E. Periodontal conditions in 35-44 and 65-74-years-old adults in Denmark.Acta OdontolSc and2006;64:65-73. 